7. Reprod. Fert. (1973) 32, 279-281.

\title{
PROGRESS IN HUMAN FERTILITY CONTROL: THE COITAL USE OF PROGESTAGENS
}

\author{
J. ZAÑARTU AND S. MANZOR \\ Unit for Fertility Research, Department of Obstetrics and Gynecology, Center for the \\ Study of Reproductive Biology (CEBRE), University of Chile Medical School, Casilla \\ 6637, Santiago, Chile
}

(Received 29th February 1972)

\begin{abstract}
Summary. From previous clinical studies, an effective oral dose was estimated for three progestagen compounds to be given only at the time of coitus. They were tested in 136 fertile women wishing to postpone pregnancy for short periods of time. Preliminary findings over a total of 814 months of observation are encouraging. Inhibition of fertility was followed by rapid establishment of pregnancy upon discontinuing medication.
\end{abstract}

Conventional oestrogen-progestagen methods of oral contraception inhibit ovulation and are highly effective. In low-dosage progestagen treatment without oestrogens, ovulatory cycles occur in about $50 \%$ of subjects (Zañartu, Rodriguez-Moore, Pupkin, Salas \& Guerrero, 1968; Zañartu, Pupkin, Rosenberg, Guerrero, Rodriguez-Bravo, Garcia-Huidobro \& Puga, 1968). The clinical efficacy of the method as assessed by Pearl's Index fluctuates between 1 and $12 \%$ (Martinez-Manautou, 1971) and seems to be related to the hour of the day when the tablets are ingested. From our observations, better effects were obtained when the dose was taken at mid-day rather than early morning; and the results were even better when the dose was taken late in the evening by subjects who usually had intercourse at night. Cox (1968) has emphasized the significance of the relationship between pill intake and coitus.

Metabolic studies of synthetic progestagens reported by Fotherby, Kamyab, Littleton \& Klopper (1968) show rapid absorption with a rather short half-life for 17- $\alpha$-ethynyl-19-norsteroids and 17- $\alpha$-hydroxyprogesterone derivatives. Since blood levels decrease rapidly, the possibility of an effective transient peak should be considered. The achievement of a 'sustained level' permitting a more uniform release at target tissues may not be as important for inhibiting fertility as was previously thought.

A surprising observation supported this assumption. It came from fertile women taking two low-dosage progestagen pills only before coitus instead of the prescribed daily pill. Intercourse frequently took place on the days on which ovulation should theoretically have occurred but fertilization was not recorded. We designed an experimental study involving fertile women who wished to become pregnant in the near future to test the possibility of inhibiting fertility by progestagens administered immediately before or after coitus. Two criteria 
of the method were studied: (1) inhibition of fertility while the compounds were used; and (2) rapid establishment of pregnancy when the medication was discontinued. Intercourse was encouraged at the expected date of ovulation, and postcoital tests were performed from 6 to $12 \mathrm{hr}$ after coitus. The urinary pregnanediol excretion (over $2.0 \mathrm{mg} / 24 \mathrm{hr}$ on the 19th to 25 th days of the cycle) and the presence of normal premenstrual progestational endometrium suggested that ovulation apparently occurred in a group of the subjects. In three women accepted for elective tubal sterilization, laparotomy was performed after the theoretical date of ovulation. The last coitus associated with the medication took place from 12 to $20 \mathrm{hr}$ before surgery. Signs of ovulation and/or a corpus luteum were found in two of the women.

This preliminary communication reports on a study of 136 fertile women each of whom had completed at least 4 months of a course of progestagen medication. With the exception of six subjects, the ages of the women ranged from 21 to 40 years (average: 24.5 ), and they had had one to seven pregnancies before the study (average: three). The average incidence of coitus was about twice a week. When coitus occurred on 4 or more days/week, continuous low-

Table 1. Glinical efficacy of oral progestagens administered to women immediately before or after coitus

\begin{tabular}{l|c|c|c|c}
\hline \multicolumn{1}{c|}{ Compound } & $\begin{array}{c}\text { Dose } \\
(\mathrm{mg})\end{array}$ & $\begin{array}{c}\text { No. of } \\
\text { women }\end{array}$ & $\begin{array}{c}\text { Total no. } \\
\text { of months } \\
\text { on treatment }\end{array}$ & $\begin{array}{c}\text { No. of } \\
\text { pregnancies* }\end{array}$ \\
\hline Retroprogestogen & 40.0 & 40 & 305 & 4 \\
Clogestone & 1.0 & 74 & 407 & 1 \\
Norgestrienone & 0.5 & 13 & 102 & 0 \\
\hline Total & 0.7 & 9 & 102 & 5 \\
\hline
\end{tabular}

* Unplanned pregnancies due to failure of the method.

dosage oral progestagens were advised to avoid uterine bleeding and cycle distortion. Three progestagens were studied:

1. Retroprogestagen (Ro-6-3129): 16- $\alpha$-ethylthio-9 $\beta, 10 \alpha$-pregn-4-ene-3,20dione;

2. Clogestone (AY-11440) : 6-chloro-3 $\beta$,17-dihydroxy-4,6-pregnadien-20-one 3,17-diacetate;

3. Norgestrienone (A-301): 17-ethynyl-17 $\beta$-hydroxy-4,9,11-estratrien-3-one.

The dose at the time of intercourse was estimated from previous studies in which the clinical efficacy of oral continuous and precoital regimens was studied (Zañartu, 1971). The results are reported in Table 1.

Five unplanned pregnancies occurred; four in women using Retroprogestagen. One subject using Clogestone was a 22-year-old mother of two children who wished to become pregnant 2 months later and was not completely sure if she had missed a tablet just before intercourse. She was classified as an example of 'method failure'. 
The acceptability of the method was surprising. Users reported that it was easier to follow and remember than the daily intake of pills.

As yet, the number of observations is too few and the observation period too short to draw conclusions but the preliminary findings are stimulating. Studies have been performed to examine the possible mechanism of fertility inhibition. Ovulation is known to occur and corpus luteum function seems normal. Typical progestational mucus changes were observed (Zañartu, 1966) but became evident only 4 to $6 \mathrm{hr}$ after the intake of progestagen. When the pill was taken for 3 to 4 days a week, some distortion of the normal ovulatory pattern of the endometrium became apparent (haematoxylin and eosin staining). There was little delay of menstruation or prolongation of cycles, considered by Swyer \& Little (1968) as signs of the progestagens' antifertility potency, and normal duration of uterine bleeding and cycles was frequently preserved: over $65 \%$ of the cycles recorded lasted for 25 to 35 days. When the pill was taken for more than 3 to 4 days a week, the incidence of prolonged irregular cycles, amenorrhoea, and/or scanty uterine bleeding increased.

Fifty-one of fifty-five women who discontinued medication conceived in the course of the same or the following cycle, further suggesting that the progestational agent administered at the time of coitus inhibited fertility.

Our observations suggest mechanisms of action other than those conventionally assumed for oral contraception. Changes in endometrium, oviduct epithelium and secretion should be explored. Recent unpublished observations by C. Oberti, M. Garcia-Huidobro and C. Gomez-Rogers show rapid cellular changes in the oviduct of subjects exposed to oral progestagens.

Other fast-acting progestagens should be tested. We have found difficulty in obtaining suitable compounds from manufacturers to be studied in such an unconventional but interesting regimen.

The authors wish to acknowledge the valuable collaboration of HoffmannLa Roche (Dr I. Werner), Ayerst International (Dr M. Gahwyler) and Farbwerke Hoechst (Dr M. Zapf) for supplying the compounds.

\section{REFERENGES}

Cox, H. J. E. (1968) The pre-coital use of mini-dosage progestagens. F. Reprod. Fert. Suppl. 5, 167.

Fotherby, K., Kamyab, S., Littleton, P. \& Klopper, A. I. (1968) Metabolism of synthetic progestational compounds in humans. F. Reprod. Fert. Suppl. 5, 51.

Martinez-Manautou, J. (1971) Low level progestagens. Nobel Symposium, 15, 53. Almqvist \& Wiksell, Stockholm.

Swyer, G. I. M. \& LitTLE, V. (1968) Clinical assessment of relative potency of progestagens.- F. Reprod. Fert. Suppl. 5, 63.

ZAÑARTU, J. (1966) Effect of natural and synthetic sex steroids in cervical mucus, penetration and ascent of spermatozoa. Excerpta med. Int. Congr. Series 133, 704.

Zañartu, J. (1971) Progestagens before coitus. VIIth Wld Gongr. Fert. Steril., Tokyo, Japan, Section for New Trends in Fertility Control.

Zañartu, J., Pupkin, M., Rosenberg, D., Guerrero, R., Rodriguez-Bravo, R., Garcia-Huidobro, M. \& PugA, J. (1968) Effect of oral continuous progestogens therapy in micro-dosage on human ovary and sperm transport. Br. med. J. ii, 266.

Zañartu, J., Rodriguez-Moore, G., Pupkin, M., Salas, O. \& Guerrero, R. (1968) Antifertility effect of continuous low-dosage oral progestagen therapy. Br. med. F. ii, 263. 